ACTA UNIVERSITATIS LODZIENSIS

FOLIA PHILOSOPHICA. ETHICA - AESTHETICA - PRACTICA 38, 2021

https://doi.org/10.18778/0208-6107.38.04

\title{
Karolina Napiwodzka
}

(iD) https://orcid.org/0000-0003-1845-7992

Faculty of Social Sciences

Adam Mickiewcz University in Poznań

karolina.napiwodzka@amu.edu.pl

\section{COMMUNICATIVE ACTION AND PRACTICAL DISCOURSE TO EMPOWER PATIENTS IN HEALTHCARE-RELATED DECISION MAKING}

\begin{abstract}
The aim of the paper is to reconsider Habermas' discourse approach in terms of its usefulness in the realm of public healthcare where, on a microscale, intersubjective communicative situations arise between defined participants, i.e., patients and healthcare providers, patients' family members, and further eligible contributors to patient-related decision making. A need for more "communicative interaction," and explicative and practical discourse, is illustrated by two empirical examples of medical decision making which reveal both communicative and discursive deficits (Section I). To empower and enable the patient as a rational and autonomous speaker and discourse participant, a Habermasian emancipatory argument and the power of the better argument' is recalled (Section III). The possibility of equal communicative and discursive rights in the light of real inequalities is discussed in the context of a 'competence gap' between participants (Section IV). Further sections focus on the importance of informed consent on the side of the patient and the communicative competences as an important factor of healthcare system.
\end{abstract}

Keywords:

public healthcare, communicative action, discourse, Jürgen Habermas, shared decision making, relations between patients and healthcare providers

\section{INSUFFICIENT COMMUNICATIVE ACTION AND DISCURSIVITY IN HEALTHCARE?}

This paper starts (in Section I) with two examples illustrating what happens when healthcare contexts dramatically neglect the need for the communicative and discursive involvement of patients as participants in medical decision making. The two examples are from the research of Liv T. Walseth et al. (2011) and they illustrate two contrasting consultations concerning patients' lifestyle changes $^{1}$ (general medicine consultations). They provide an empirical argument

\footnotetext{
${ }^{1}$ It is worth noting that the subject of lifestyle changes has particular moral potentials because it concerns the patient's daily life and decisions. As Walseth et al. mention, "Our premise is that
} 
in favor of making communicative action and discourse more present and useful in healthcare contexts. Similar examples may be found in nearly all sectors of public healthcare. In Sections II-VII, I will present several theoretical arguments and reasons drawn from Habermas' approach to practical, explicative and innovative discourse to support my thesis, according to which there is a need for practicing more communicative action and discourse in decision making within healthcare contexts.

\section{AN EMPIRICAL ARGUMENT WITH TWO EXAMPLES BY WALSETH ET AL}

The following empirical examples present two medical encounters within primary care. It may be worth noting that in this area it is relatively easy to observe some deficiencies in the communication between the patient and medical professionals (patients and physicians have an opportunity to get to know each other better because they continue therapy for a long time). However, discursive and communicative deficits are visible at all levels of healthcare. I assume the division into the microsphere, which centers around the doctor's office - the relations between patients (eventually other defined third parties) and the healthcare providers. In the middle there is the level of medical facilities and the macro, where universal justifications at the level of healthcare as a system are concerned (compare Lee and Emmott, p. $610 \mathrm{ff}$ ).

\section{Consultation A}

Duration 34 min. A hypertensive, obese man in his forties has his fourth consultation with a relatively inexperienced male doctor who is a substitute for the regular doctor. The doctor offers general advice, rarely adjusted to the patient's situation, and takes few initiatives to explore or comment on the patient's lifeworld. The patient's speech acts repeatedly introduce lifeworld issues. The doctor counters this by changing the subject (4 times), interrupting (twice), offering general advice without changing the subject (4 times), exploring objective lifeworld (twice), and supporting a theme from the patient's subjective lifeworld (once). The doctor performs 34 speech acts, the patient 18. The topics of the doctor's advice were: diet, activity, the importance of using time, lifestyle change is difficult, and lifestyle changes have to be individualized.

This consultation starts from the information offered by the patient and the verbalized expression of his concerns: he was on a course, lost weight, but then gained weight again. The patient wants to share his anxiety with the doctor and describe what he thinks the source is. However, the doctor immediately offers

lifestyle is patterned by everyday decisions rooted in the individual's ethical assumptions and aspirations. This is normatively founded in ethical theory" (2011, p. 180). 
general advice: follow-up appointments, to log food intake, and to engage in activity. Then, the doctor measures the patient's height, weight, and waist, and does not notice that the patient "takes initiative to reflect over his adolescence with a lot of cookies and a sedentary life because of asthma and mentions fear of early death like his grandfather" (Walseth et al., 2011, p. 182). The doctor does the paperwork without paying attention or responding to the patient's narrative. In a later part of the consultation, the patient talks a few times about his fears and offers details from the past that undermine the legitimacy of following the doctor's recommendations. One of the details is also important from a medical point of view - the previous year the patient thought that he had had venous thrombosis, and he can still feel something in his leg. The doctor ignores the patient's experience, fears, and intuitions, while still offering general recommendations. The doctor's main goal is to identify a medical problem, but in the course of this task this doctor does not perceive the patient as an individual: his experiences, his perspective voiced from "the lifeworld," and his individual problems. After the consultation the patient has the impression that he has not been treated as an equal conversation partner, but rather as a stereotypical case. The advice given by the doctor was too general to be of use. In addition, the patient felt that the doctor did not treat his knowledge as worthy of being taken into consideration. The doctor had no need of the knowledge derived from the lifeworld in order to make a diagnosis and draw up a treatment plan: he seemed to have devised a treatment plan before hearing any information from the patient. This case could be seen as extreme in terms of strategic action because the doctor's goal is not to reach an agreement through discourse or deliberation.

\section{Consultation B}

Duration 23 min. A woman in her thirties sees her female doctor for the fourth time - an experienced doctor. The patient is overweight, has fibromyalgia, a tremendously stressful situation at home, and needs help with finding a new job accommodated to her health. The doctor performed 50 speech acts, the patient 37. Typically, the doctor summed up and interpreted the patient's statements concerning her situation. The patient responded with confirmations, typically adding more information concerning everyday life. The doctor explored emotions in seven speech acts, explored the objective setting in nine speech acts and explored the social setting in one speech act. The patient responded positively to this exploration.

In Consultation B, the doctor paid attention to the patient's narration. All the speech acts contain information which may be potentially relevant for the treatment. The doctor summarizes what bothers the patient (pain in the leg and a stressful situation at home), confirms this (adds that "it makes it difficult to work"), and interprets ("it must be frustrating"). When the patient mentions her 
stressful domestic situation, the doctor summarizes and explores further. Then, the patient adds more information concerning her problems and the doctor summarizes again, saying that "it is hard to find the way forward." In addition, she reminds the patient to take care of herself and asks if her cohabitant helps with the chores at home. During this consultation clear decisions are made: the patient is going to start with psychomotor physiotherapy, continue her work training, and make a new appointment. She is not going to increase physical activity.

If we consider the various speech acts (according to the authors of the study, they are information, summary, confirmation), in the first consultation they do not lead to agreement as to the best course of treatment for the patient. Moreover, in Consultation A, the participants of the interaction break a series of discourse rules. Firstly, the rule of respect for the interlocutor, who in this situation has practically no opportunity to become a conversation partner. As a consequence, the rule of inclusiveness (the availability of discourse for everyone and the possibility of expressing oneself within the limits of one's knowledge) is broken. Secondly, there is no place for the rule that space should be made available to the interlocutor. Thirdly, the rule of responsiveness and shared responsibility (the doctor does not motivate the patient, to make him empowered and mobilized, but rather makes him passive, e.g., Napiwodzka, 2021). Fourthly, the patient has no opportunity to explain his emotions. They are not taken into account in the diagnosis and in establishing the treatment plan. Finally, in this case, the doctor does not accept that there is a need for the communicative involvement of the patient; nor does the doctor create any room to allow the patient exercise his right to communicate.

According to Habermas, communicative competence is by definition the interactive and consensual, practical ability to reach a mutual understanding, therefore, the one-directional communications of the doctor do not meet this definition. As a medical professional, he has expertise and scientific knowledge which, in his opinion, is sufficient to make decisions concerning both the patient's health condition and everyday life. Given the above, it could be noticed that there is a need to improve patient and healthcare providers relations through effective communication. Extensive research in this area has already provided many useful tools. However, in the following sections of this paper, the author will focus on tools derived from practical discourse which are applicable in the field of primary healthcare, where numerous crucial decisions are made. In this respect, the paper offers a new perspective. As a consequence of the medical decision-making model evolving from paternalist to communicative, deliberative and discursive, "primary care services include initial diagnosis, treatment of general medical problems, and referral to specialists when necessary" (Lee and Emmont, 1978, p. 613) and require more than the formal and silent consent of a patient. They need informed and argued consent, or even agreement based on shared and reciprocally accepted reasons of critical importance. 


\section{EMPOWERING PATIENTS IN THEIR EMANCIPATORY INTEREST}

Since the beginning of interdisciplinary bioethical reflection in the 1960s, scholars - and also healthcare providers - have wondered how to reconcile the different views, interests and validity claims expressed in the process of making difficult medical decisions. The history of twentieth-century medicine demonstrates the need to include representatives of various medical professions, related professions, patients directly involved, and other laypeople in healthcare discourse (see Engelhardt, 1986; Rothman, 1991). One of the main barriers that prevents such a broad involvement of communication and discourse participants seemed to be (and still seems to be) participants' insufficient communicative and discursive competences, and the asymmetry between those who embody professional medical expertise on the one hand, and, on the other, those who are to be diagnosed, treated, cared for, etc. but having little or no medical knowledge and experience. But making healthcare related decisions is not exclusively based on and justified by professional knowledge or expertise. Otherwise, why should patients have their autonomy and their right to declare their so-called informed consent?

Advocating for the communicative and discursive participation of all parties in the healthcare context, as parties representing various social rules and epistemological backgrounds, might give the impression of going against the stream: since they are oriented towards effective treatment, healthcare facilities and healthcare providers would have a preference for strategic discourse and strategic (inter)action:

Strategic action occurs when at least one party - in this study clinician, patient or interpreter - aims through speech to produce an effect on others. In other words, he or she instrumentalizes speech for purposes that are contingently related to what is said. Strategic action is oriented to success (what might be called an ulterior motive) rather than to understanding. It can take a number of different forms. In open strategic action, a speaker openly pursues an aim of influencing the hearer(s), and there is an associated claim to power (as in giving an order to a subordinate). Concealed strategic action involves confusion between actions oriented to understanding and actions oriented to success, resulting in what Habermas calls communication pathologies,

as Trisha Greenhalgh et al. put it (2006, p. 1171).

Increasing patients' participation in decisions and agreements towards a treatment process (see Elwyn et al., 2016; Langford et al., 2019; NewtonHowes et al., 2019) would not necessarily accelerate strategic and effective action in medical contexts. Rather, it would expand beyond the basic and standardized medical processes including diagnosis and treatment, enriching these processes with novel social qualities. Taking into account an increasingly advanced medical setting, one could ask: To what extent should patients be 
involved in decision making on their health - which is, after all, both an individual and a social good? Or, what level of professional knowledge related argumentation and what level of argumentation based on other sources represented by patients would meet together halfway, to make up a common, discursive justification of medical decisions? At the same time, people communicate and argue one with another not because they personify the same knowledge, similar experience, following common values and beliefs. On the contrary, people communicate because they are different on epistemological and normative levels, and involved in different situations. They transform their "assertives" into "communicatives" to reciprocally understand their "constatives," "regulatives," "declaratives" etc., and then, to get through the next step in which their "naïve" and "controversial" claims for validity (rightness) will be argumentatively proved - and justified - in order to reach an agreement in the practical-normative sense of this term. Communication and discourse have been invented for subjects who are different and inequal, but who are nevertheless able to develop communicative and discursive competences strong enough to overcome inequalities, and to promote their emancipatory interest (see also Szahaj, 1990). Therefore, searching for more patient participation in medical decision-making contexts can be associated with their emancipatory (see Stefaniak, 2011) interest interpreted as shown above, as decision makers with equal communicative and discursive rights.

Until now, the discursive modalities of medical decision making have been underexplored. However, there is a lot of scholarship describing medical and healthcare discourse, e.g., hybrid discourse in "medical communities" (Swales et al. 2016) and shared decision making. All these concepts tend to relieve (or to emancipate) both patients and healthcare providers from paternalist models (except situations in which paternalism and care are unavoidable) on behalf of modus and models involving patients (and defined third parties - patients' caretakers, family, law agents) in medical decision making, without forcing the patient. From the legal point of view this is possible through such institutions as the patient's autonomy, informed consent, patient's basic rights etc. However, these institutions and legal tools do not exhaust possible ways of empowering patients in situations of clinical decision making.

Considering in this article the conditions under which both the patient and other participants of the decision-making situation within public healthcare could be more active and involved in terms of communicative interaction and practical discourse, the author of this paper joins scholars already attracted by this paradigm (Scambler, 2001; Alex Gillespie et al., 2013; Granero-Molina et

\footnotetext{
2 Already existing institutionalized social rules and procedures, i.e., see Habermas, 1971, pp. 111-112. Furthermore, "behavitives" in terms of established and institutionalized performatives according to Austin (Habermas, 1971, p. 112).
} 
al., 2015; Leanza et al., 2013, pp. 13-25; Hvidt et al., 2021; Walker and Lovat, 2016), or who are at least focused on the shared decision making, as well as on improving a patient's rational and autonomous participation in judgments, decisions and solutions which address a patient as an "object." The attempt to emphasize that the patient lacks the status of a "subject" is associated not only with more openness, transparency and explicitness in medical decision making that addresses patients as "objects"; it is also associated with openness to the claims of others, which is another aspect lacking in both paternalistic and expertise-based models of medical decision making. Walker and Lovat have proposed strengthening the basis for reaching a consensus (agreement, reconciliation) by means of dialogue in medicine. Other scholars have broadened the assumptions of the model of shared decision making and the deliberative model (Emanuel and Emanuel, 2004) through reference to so-called "bioethical mediation" and "assisted conversation" (Fiester, 2015; Walker and Lovat, 2016). Their approaches would facilitate the search for the best possible solutions for a specific patient in a specific situation ("perceiving patients' ethical dilemmas as specific existential situations", as described by H. Carel, 2011). These scholars view the process of reaching agreement together with a patient as a high socio-moral value that corresponds to another high value, i.e., human health.

Habermas advocates for basically unlimited access to communication, for openness to the claims of others, for discursive examination of those claims, and for the agreement among all participants. His practical discourse theory will be revisited here not to explore ideas, but to explore how strongly a Habermasian approach would empower patients as participants of medical decision making. Discursivization can also be recommended in the sense of symbolic emancipatory interests. It is also advisable in the light of another, basic fundamental "asymmetry" between patient and doctor. The patient is under the care of health providers, which makes their position automatically weaker (as a patient). The purpose of this argument is not to question this relationship, naturally based on a (kind of) dependence sensu stricte and sensu facto ("the patient's health is in the hands of the doctor"). However, one may question whether that patient is "dependent" on the other subject (i.e., a healthcare provider) as a rational, autonomous subject. Such a dependence could become a part of the "control" of one entity over another. The statutory rights of patients within modern healthcare systems could be seen as a form of preventing (or eliminating) such a form of dominance. The author proposes to interpret the potential of autonomy, informed consent and a number of other rights that involve the patient in relation to healthcare providers and healthcare institutions, precisely in the categories of communicative action and discourse. 


\section{ON THE PROFESSIONAL "COMPETENCE GAP” BETWEEN DOCTORS AND PATIENTS}

If we consider the situation of a medical encounter (consultation) in which the doctor and the patient meet for the first time' the professional voice (the voice of medicine) collides with a non-specialist one (the voice of the lifeworld). The relations between medical professionals and laypeople are necessarily and multifariously imbalanced, since one of the parties has knowledge that the other lacks (which is typical for nearly all social relations except professional ones). The "competence gap" (see Jones, 2001) in the medical encounter may be caused by medical language which is difficult to translate into the language of laypeople. ${ }^{3}$ Linguistic competence is, however, one of several reasons for such asymmetry in medical practice. Although the doctor-patient asymmetry is largely rooted in the participants' different (or, more precisely, disproportionate, asymmetric, incommensurable) linguistic competences, it seems to feed further asymmetries. There is a "competence gap," deepened under time pressure, and especially in the face of difficult disease experiences. Asymmetry factors include: the institutional environment; expert knowledge and experience; the doctor's power and control over the discourse rules; the age and sex of the doctor and the patient; the doctor's authority; medical specialization; the purpose of the visit; and the presence of the patient's relative (or representative).

To bridge the "gap," Kodeks Etyki Lekarskiej ${ }^{4}$ (2020) addresses the following recommendations: a healthcare provider should talk with patients in an understandable - thus, transparent and lucid - language. ${ }^{5}$ In Habermas' terms, this would facilitate agreement (Verständigung) as sharing the maximum of meaning conveyed by a speech act. However, applying this rule in daily communicative practice, which involves persons from different educational, cultural and social backgrounds, would require additional explicative means. At the same time, however, communicative competence can be trained and learned, just like any other competence. Therefore, articulate speech would be the key skill in a doctor-patient relationship, before the former applies his specialized medical technai on the latter.

\footnotetext{
${ }^{3}$ For a more detailed discussion of laypeople in medical decision-making contexts, see Rothman, 1991.

${ }^{4}$ The Polish Medical Code of Ethics.

${ }^{5}$ Compare the recommendations of the "Program akredytacji podstawowej opieki zdrowotnej (2011, pp. 22-23)". According to PP2 (Patient's rights), "Patients must receive transparent and communicable information about their health condition" (supposedly: provided by medical practitioners by means of conversation). According to PP3, "Patients can freely participate in medical decision making".
} 


\section{EQUAL RIGHTS TO COMMUNICATIVE ACTION \\ AND DISCOURSE PARTICIPATION ACROSS REAL INEQUALITIES AND A COMMUNICATIVE COMPETENCE “GAP”?}

When defining communicative and discursive action, Habermas applies the term "communicative competence" whose maturation/development ("ontogenesis") requires favorable socializing and educational opportunities. The complexity of this competence might have frightened scholars who tried to describe its developmental "stages," inspired by Kohlberg. However, all the addressees of Habermas' theory could be much more intimidated, as every single subject engaging in communication and discourse should be able to employ that complex, communicative and discursive competence. The necessity of observing some rules and arguing rationally to justify (Habermas, 1971, p. 115) the outcomes of communication, i.e., statements and their "claims" for validity in social discourse, seems to apply to everybody: especially because communication and discourse have their intrinsic, inclusive and emancipatory power.

In fact, defining communicative competence "by the ideal speaker's mastery of the dialogue-constitutive universals irrespective of the actual restrictions under empirical conditions" (Habermas, 1971, pp. 140-141) sounds demanding for real subjects. Real subjects tend not to embody ideals. Rather, their rationality and communicative (and discursive) abilities operate at a "different speed." Nevertheless, both their individual ontogenesis and their manifestation depend on various factors. There is no absolute equality among communication and discourse participants. Only equal opportunities (chances) or equal rights can be taken into consideration. As the equal chances approach originates from Habermas' discourse ethics and addresses real discourse participants, it deserves analysis in this section.

There is a third kind of discourse invented by Habermas to bridge the gap between idealized and empirical communicative-discursive situations, i.e., a supportive discourse addressing a real speaker (just a speaker who "anticipates" their ideal role) or, in other words: the "explicative discourse," as described in Theory of Communicative Action. Explications enable participants to 1) better understand one another (especially the complexity of "symbolic" speech) and 2) to achieve equal discursive chances (Habermas, 1971, p. 115). Their multilateral understanding should minimize the extra-discursive constraint and lead to the virtualizing of the forces which affect human action and forces with which human action affects activities and the actions of other subjects 
(Habermas, 1971, p. 117) ${ }^{6}$, and - finally - equalize the discursive opportunities of participants liberated from any external (material, social) and internal constraint. ${ }^{7}$ There is no absolute equality between real discourse participants. A patient's basic rights, such as autonomy and informed consent also support the equality of discursive opportunity for patients and healthcare providers. Thus, a real patient's potential discursive competence is promoted in the following way: as a cognitive ability (promoted through the third kind of discourse, namely "explicative discourse", including interpretation and clarification. Explicative discourse is critical and "therapeutic," especially in regard to interpreting symbolic propositional expressions and preparing the background for making the claims to claims to truth, rightness, validity, etc., impartial.

Freeing a subject of their internal constraints, including immediate interests and performative contradiction, is not only "therapeutic," but also educational - namely, it corrects a subject's "cognitive schemes of interpretation" (Habermas, 1970, p. 364) to overcome subjectivism and to advance on the level of intersubjectively shared, universalizable (Habermas, 1970, p. 364) contents and claims. In this way understanding one's own and others' statements within "the intersubjectivity of meanings" (Habermas, 1979b, p. 6) and clarifying them beyond differences and conflicts, according to logical and semantic "comprehensiveness, universality and consistency" (Habermas, 1979a, p. 77), become possible. Learning this, both "actors and their needs also grow (...) to the symbolic universe (...) To the increasing mastery of the general structures of communicative action (...) there correspond graduated interactive competences" (Habermas, 1979a, pp. 84-86), that is, social discursive competences.

A right to voice one's own interests, reasons and arguments autonomously and openly as a social discourse participant is rooted in a subject's freedom of double constraint. A subject can then cooperatively create "a domination-free discourse," as a situation free of both internal and external coercion and dominion claims of any kind (see Habermas, 1984). As "force and fraud stand opposed to rational persuasion" (Habermas 1987, p. 212) and to "the unforced force of the better argument" (Habermas, 1998, p. 37). However, administrative powers would be allowed to cross discourse according to Habermas.

\footnotetext{
${ }^{6}$ Originally, Habermas describes a discursive process of laying down the participants' arms in the following way: "discourses assert their own claims, according to which (...) shall be suspended in order to disarm all action incentives except incentives supporting a cooperative willingness to reach agreement and supporting the detaching of validity related issues from the issues related to participants' original interests"; as validity claims should be justified on the basis of strong and community-level arguments, "not on the strength of someone's immediate interests" (Habermas 1971, p. 117).

${ }^{7}$ Constraints may be linked to determinisms, incentives and interests, but not all determinisms and incentives are constraints.
} 
Importantly, the "explicative discourse" should facilitate - and mediate - a transition between the communicative (inter)action aiming at the reciprocal understanding (Einverständnis) on the one hand, and, on the other hand, practical discourse aiming at reciprocal agreement (Verständigung) on decisions, solutions, new regulations and rules, and effective ways of acting, supported by validity claims actually recognized by all participants.

No ability involved in discourse should be regarded as an asocial and isolated one, including the capacity for articulate speech. Habermas describes a global, non-monological (Habermas, 1970), cognitive "ability" rooted in one's individual knowledge, understanding and experience (Rodrian-Pfennig, 2014, pp. 24-25). It is followed by "a disposition enabling a person to effectively solve certain problems and to cope with certain challenges" (Klieme et al., 2007, p. 72). Fostering those (and further abilities such, as "one's might, action, (...) motivation," as Rodrian-Pfennig (2014, pp. 24-25) continues would finally promote - and also make explicit and considered - the strategic ability in sensu Habermas, i.e., "the ability to act purposively" (Habermas, 1992, p. 134), in the participants of communicative and discursive interactions. Within a Habermasian system of communicating vessels, a successful agreement allows participants to coordinate related practices (Habermas, 1992, pp. 134-136). Thus "they differ in that for the model of strategic action, a structural description of action directly oriented toward success is sufficient, whereas the model of action oriented toward reaching understanding must specify the preconditions of an agreement, to be reached communicatively, that allows alter to link his actions to ego's" (Habermas, 1992, p. 134).

To summarize, having equal communicative and discursive rights enables subjects to participate in both communication and discourse which lead to making non-particular, non-arbitrary, justified decisions and solutions with practical implications. Being a competent actor of communicative and discursive interaction presupposes the ability to respect the rules of communication and discourse, which are equal to all participants. This seems to be possible in healthcare contexts, although not all kinds of decisions and solutions must be (and can be) made by means of discourse and communication in Habermasian terms. The readiness of all the involved parties to engage, and the readiness of all involved institutions to promote, legitimate and respect a patient's participation whenever the latter is possible, would constitute a minimum normative precondition of healthcare's discursivization (which can be understood as making healthcare delivery more discourse-based). Potential readiness and at least a rational-discursive capacity are to be taken into account when considering the discursive ability of interpersonal judgment, and decision and solution making in healthcare contexts. 
PROFESSIONALS VS. LAYPEOPLE UNABLE TO MEET HALFWAY

IN COMMUNICATIVE AND DISCURSIVE INTERACTION? HABERMAS' TWO SUPPORTIVE DISCOURSES TO BRIDGE THE "COMPETENCE GAP”

How serious is the "competence gap" (Jones, 2001, p. 74) between healthcare providers (medical professionals) and patients as laypeople? In the light of communicative action and discourse theory, if the outcomes of communication have yet to be justified, if their meaning may not be clear to other parties, then explicative discourse (described by Habermas in his Theory of the Communicative Action) is recommended, and this occurs regardless of the subjects' status, professionalism, experience etc. Transferring one's knowledge in the form of a speech act to others does not automatically imply being adequately understood. Nor does it entail subjects' communications and their validity claims becoming immediately depersonalized, de-particularized and "virtualized", as Habermas puts it. This can also concern all the participants of medical communication: both medical professionals and patients first explain their reasons to each other to meet halfway and to agree upon them.

Communicative action refers to interaction that is mediated through talk and oriented to an agreement that will provide a basis for a "consensual coordination of individually planned plans of action". Instances of communicative action express criticizable validity claims (...) it is possible to claim that the communication is true or not true, appropriate or inappropriate, justifiable or unjustifiable, and also that it is sincere or not sincere. All these claims can also be challenged. Speakers can "rationally motivate" hearers to accept their contributions because they can assume the "warranty" for providing good reasons that would stand up to hearers' challenges of validity claims. Whilst challenges to a speaker's validity claims for truth, appropriateness and justification can be redeemed discursively through talk, those concerning sincerity require practical demonstration,

as Trisha Greenhalgh et al. assume (2006, p. 1171).

But can patients question medical professionals" "constatives" and their claims for their being true, proper, right, or valid? Narly all of their constatives are based on their professional expertise and scientific knowledge, however, not all medical constatives are immediately understandable to laypeople. The "questioning" of them (and their validity claims) by patients encompasses them asking a doctor for clarifications and explicates in order to facilitate their understanding of a medical professional's communications, despite their problematic status. This makes possible the first, semantic and symbolic virtualization of agreement on constatives, that is, detaching them from a healthcare provider's immediate interest, especially, because a healthcare provider has no personal interest in validity claims. They are acting - also as a participant of 
communicative and discursive situation - in the interest of their patient. Hence, it seems to be enough if, in order to pass to the justification of problematic validity claims, all parties arrive at the same interpretations of a patient's interest. Justification should be possible through discourse (Habermas, 1971, p. 117).

Among the many issues arising when discussing healthcare related decision making in terms of communicative action and discourse theory, one might sound particularly controversial: Do patients question the "constatives" of medical professionals, which are documented and justified by medical expertise, and supported by evidence and scientific knowledge? Yes - regardless of the fact that patients' contributions draw on their personal experience, medical and social biographies, and their "Lifeworlds." Svenaeus is right when highlighting (in true Habermasian spirit, as will be explained below) that "medical practice is not applied science, but rather interpretation through dialogue in service of the patient's health" (2003, p. 419).

Therefore, patients can express relevant information, arguments and validity claims, which will be further interpreted, examined and taken into account by healthcare providers, and will provide an additional touchstone when diagnosis, medical advice or prognostics are formulated. Clarifications, explications and interpretative efforts oriented towards the unconscious and unspoken intentions of speakers must be undertaken by all participants. Once the explications become one-sided, i.e., without the other as a speaker, the other is treated as an object and not a subject (Habermas, 1971, pp. 118-119), and they are ascribed unintelligible, a-rational motivations, intentions, etc., which are "dark" in discursive terms and slip out of discourse standards and rules. Here, as healthcare (unlike legal institutions) seems to be more open to social and individual (even private) spheres of life and experience, Habermas - repeatedly discussing with Robert Brandom - assumes that

the communicative exchange always takes place against the background of an implicitly accompanying discursive shadow theatre, as it were, because an utterance is only intelligible for someone who knows for what reasons (or for what kind of reasons) it is acceptable (Habermas, 2009, p. 72).

Hence, a communicative and discursive exclusion produces (or at least escalates) that which can be called irrational and dark, and what is nowadays frequently ascribed to personal "Lifeworlds". Although the two or more outlanders involved in a communicative and discursive situation have insufficient knowledge regarding their motivations and intentions as speakers, they have at least two, far superior solutions than making one-sided, instructive, lecturing or paternalizing ascriptions. They can engage - as Habermas recommends -1 ) in a therapeutic discourse, as already mentioned in Section II, or 2) in an innovative discourse. Exploring a therapeutic discourse in his early 
and later writings, Habermas compared it to a psychoanalytic conversation through which a medical doctor fosters his patient's self-reflection. The "therapeutic discourse" serves to prepare the mutual "conditions of the possibility of discourse" which is possible by methodically requesting for "self-reflection" as a kind of "psychoanalytic conversation between doctor and patient” (Habermas, 1971, p. 121; compare Habermas, 1987, p. 366) using narrative and dialogical tools. "This relation therefore differs from a classic layexpert relation (such as the one between a doctor, whose role is to have authority, and a patient, whose role is to recognize the doctor's authority)" (Celikates, 2018, p. 151) which additionally supports the discursive approach to healthcare, as argued for in this paper.

Again, the role of innovative discourse would be to make communication and discourse participants (let them be doctor and patient) more familiar with one another, that is, to protect them against ascribing motivations and intentions in a one-sided, paternalizing, instructive way: "a discourse oriented towards innovative contents, both informative and instructive for participants, and meeting a Humboldt's model present in open-ended and free seminar-discussions" (Habermas, 1971, p.121).

Now we see that many obstacles, asymmetries based on different knowledge and on being rooted in different institutional or "Lifeworld" related contexts, and also the more or less radical inequalities between subjects engaging in a communicative and discursive interaction, could be levelled and balanced using a wider choice of discourses, as e.g., that of Habermas himself. Walseth et al. put forward several supportive arguments which can be used here to sum up the present section and to announce the next one:

According to Habermas, an ethically sound decision should originate in a respectful explorative dialogue, where the participants consider the relevant concerns from three dimensions of the patient's "lifeworld": The objective concerns are those that make a decision practicable, the subjective concerns denote personal wishes and feelings, and the social concerns include perceptions of right and wrong ways to act towards other people. A good dialogue should aim at an exploration of and reflection upon the patients' reasons for his or her opinions and acts. The reasons are constituted of values and norms that the patient uses to direct her or his actions, and can be clarified by questions like: What is practically possible for you? What is good for you to do? What is right for you to do? The goal is to reach a reflective equilibrium where an ethical judgment has evolved from reflecting jointly upon the patient's context and his or her moral and personal experience (2011, p. 181).

To Habermas, to answer all the questions mentioned by Walseth et al., several discourses are needed. Two of them were presented above. Below the role of practical discourse in healthcare contexts will be examined. 


\section{PRACTICAL DISCOURSE AND THE HEALTHCARE CONTEXT}

"A normative discourse theory" (Alexy, 1978, p. 225), also called practical, cannot be limited to the application of the discourse paradigm to jurisprudence and lawmaking because, as Habermas highlights in "Vorbereitende Bemerkungen," "Verständigung" (understanding-based agreement) is a normative notion (1971, p. 123) and applies to all kinds of intersubjective practical judgments, decisions, arrangements, etc. that are claimed to be of normative value, such as a right and just decision. Their proponents lay claim to recognition, validation, or legitimization by all the participants involved in the argumentation procedure and showing sufficient argumentative competence. The notion "practical" originally refers to Kant's practical reason, an autonomous "law-giver" that is able to prove one's practical maxims by using the test of the categorical imperative. In Habermas' thought, the socially situated rationality of communicative interaction and discourse, which is intersubjective and open (i.e., no longer limited to a single subject's reason conducting the "test" utilizing their tacit reasoning), would be the equivalent of Kant's practical reason.

However, not only moral "maxims" are argumentatively and reflexively proven by participants to become acceptable and "universalizable" and attain the status of valid "norms" (be they real or only hypothetical, as was the case in Kant). There can also be important judgments, evaluations, decisions, commitments, arrangements and other forms of "agreements" achievable by means of discursive interaction. Discursive procedure was repeatedly considered - and also inspired - by Lawrence Kohlberg's Stage/Orientation 5 related procedure, according to which judgments, decisions, commitments, etc. become intersubjectively valid and shared on the bases of an understanding-based agreement between subjects.

Intersubjective agreement should advance judgments, decisions or other practical (non-theoretical) statements expressed by subjects in their speech acts and provided with naïve, partial - and thus "controversial" - claims for validity, which are yet not proven or recognized by others. Before such an agreement can be successfully achieved, it is necessary to conduct an argumentation procedure. Practical discourse can be defined as the quest for right and just judgments, decisions, novel or revised social rules (according to the "law-giving" function of reason), etc. Unlike practical discourse, theoretical discourse can be defined as the quest for truth (Wahrheitsanspruch), adequacy, and other epistemic and epistemological values.

Medical practical discourse is institutionally defined as a discourse oriented towards values, priorities and principles shared by nearly all human beings in all cultures. Improving health and well-being, and eliminating pain and suffering, belong to the normative framework of discourses conducted within the healthcare context. The principles, regulations and procedures of a healthcare 
system can be regarded as "regulatives" and their presence in medical practical discourse is obvious. The already existing and objective "regulatives" may also contribute to a "necessary justification" (Habermas, 1971, p. 123) between participants of a small group (microscale) which make efforts to achieve a bilaterally (or multilaterally) justified and acceptable decision, commitment or arrangement, whose validity rises from recognition by all the involved parties, being, at the same time, a validity related to and respected and observed by the participants of that group. A micro scale discursivity would suit the specific contexts of medical and healthcare related decision-making: these contexts are limited to a concrete patient's health condition, critical needs and interests which are, however, common and central to all the participants involved, in particular to healthcare providers. Paradoxically, an individual patient's interest is regarded as each participant's common and consensually prioritizing of a related, communicative or discursive interaction. Such a community of interests seems to be one of the facilitators of possible recognition acts and agreements, beyond the different epistemic backgrounds represented by individuals.

\section{CONCLUSIONS AND DISCUSSIONS}

Discourse Theory (in particular Practical Discourse Theory) would create new potentials for application in healthcare related decision-, arrangement-, and agreement making. Within the micro-communities consisting of defined subjects as communication and discourse participants who meet together to make medically important judgments and decisions concerning a patient and their health condition, which are situated in a social world and Lifeworld (and this applies to both the patient and their health condition), shared, reflexively argued and reciprocally accepted agreements including arrangements, decisions, commitments, etc. can be aimed at. Implicit agreements and shared decisions seem to be - although only scarcely - anticipated by the legal institution of a patient's informed consent. Deficits in the area of medical communication between patients and healthcare providers are also challenging researchers to explore new tools for improving communicative and discursive qualities and competences with regard to their research topics. Certain questions were formulated and discussed in this paper.

However, numerous remaining issues require future research. The "gap" between epistemic competences can be smoothed by means of explicative discourse, and also by the reciprocal recognition of the different epistemic capacities personified by healthcare providers and patients. As the approach which takes social perspective into account shows (and this is also present in the early Habermas, namely in his essay Moral Development and Ego Identity), 
subjects learn to understand the cognitive and normative perspectives and viewpoints of other subjects, and shape social cognition. This skill would increase the chances for conflict resolution and discursively achieved agreement.

The second important - but still disputable - issue would be distinguishing the emancipatory interest expressed by Habermas as a "virtualization" of all the a-rational or nonrationalizable pressures surrounding and influencing participants situated in their Lifeworlds and interdependent on their social context, but unavoidably motivated by their immediate health-, wellbeing-, and welfare interests which - fortunately for Discourse Theory - are exemplifications and concretizations of socially and publicly recognized - and institutionalized - common and universal principles. The kind of life pressures that are experienced by patients, e.g., as pain, suffering, stress, helplessness, and other strong emotions that usually accompany an illness, cannot be removed from the context of medical decision and agreement making by means of discourse. Medical discourse remains sensitive to them, and also often transforms them to relevant "constatives" when exhaustive evidence is lacking.

It is not only in medical and healthcare related contexts that discourses fail to lead to an "ideal" agreement and validity. Instead, they pave the way to "real" agreements and validations which may only anticipate ideals. Their intersubjective reciprocal recognition would decide what can be claimed as right, just, committing and valid. Accepting speech acts which refer to Lifeworlds, to first-person experiences, personal, private and intimate contents belonging to the "shadow theatre," discourses show their irregularities against the "idealizing" presuppositions of the discourse and communicative action theory proposed by Habermas. Real discourses seem to be an amalgam of communicative and discursive practices and utterances which constantly pretend to plausibility, recognition and validity, but do not always become truly valid. Sometimes, participants treat something as true without plausible references and interpretations by others. This can be related to the different linguistic games played by speakers or their different experience horizons. "Distinguishing between truth and taking-true can remain up to each individual participant in discourse." 8 In medical communication and discourse open to the Lifeworlds, Brandom's metaphysical realism seems to be a useful corrective (in the pragmatic and practical sense) of Habermas' Discourse Theory.

\footnotetext{
${ }^{8}$ Habermas explaining Brandom's “anaphora” (Habermas, 2003, p. 143 and 166).
} 


\section{BIBLIOGRAPHY}

Alexy, R. (1978). Theorie der juristischen Argumentation. Frankfurt am Main: Suhrkamp.

Carel, H. (2011). Phenomenology and Its Application in Medicine. Theoretical Medical Bioethics, 32 (1), pp. 33-46.

Celikates, R. (2018). Critique as Social Practice. Lanham: Rowman \& Littlefield Int.

Elwyn G., Frosch D. L., and Kobrin S. (2016). Implementing Shared Decision-Making: Consider all the Consequences. Implementation Science, 11, pp. 1-12.

Emanuel, J. E. and Emanuel, L. L. (2004). Vier Modelle der Arzt-Patient Beziehung. In: Wiesing U. (ed.), Ethik in der Medizin. Stuttgart: Reclam.

Engelhardt, H. T., Jr. (1986). The Foundations of Bioethics. Oxford: Oxford University Press.

Fiester, A. (2015). Neglected Ends: Clinical Ethics Consultation and the Prospects for Closure. The American Journal of Bioethics, 15 (1), pp. 29-36.

Gillespie, A. et al. (2013). Beyond Ideal Speech Situations: Adapting to Communication Asymmetries in Health Care. Journal of Health Psychology 19 (1), pp. 72-78.

Granero-Molina, J. et al. (2015). Habermasian Knowledge Interests: Epistemological Implications for Health Sciences. Nursing philosophy. An International Journal for Healthcare Professionals, 16 (2), pp. 77-86.

Greenhalgh, T., Robb N., and Scambler G. (2006). Communicative and Strategic Action in Interpreted Consultations in Primary Health Care: A Habermasian Perspective. Social Science \& Medicine, 63, pp. 1170-1187.

Habermas, J. (1970). Towards a Theory of Communicative Competence. Inquiry, 13, pp. 360-375.

Habermas, J. (1971). Vorbereitende Bemerkungen zu einer Theorie der kommunikativen Kompetenz. In: Habermas J. and Luhmann N., Theorie der Gesellschaft oder Sozialtechnologie. Frankfurt am Main: Suhrkamp, pp. 101-114.

Habermas, J. (1979). Moral Development and Ego Identity. In: Habermas J., Communication and the Evolution of Society. Translated by T. McCarthy. Toronto: Beacon Press, 1979, pp. 69-94.

Habermas, J. (1979b). What is Universal Pragmatics? In: Habermas J., Communication and the Evolution of Society. Translated by T. McCarthy. Toronto: Beacon Press, pp. 1-68.

Habermas, J. (1983). Moralbewußtsein und kommunikatives Handeln. Frankfurt am Main: Suhrkamp.

Habermas, J. (1984). Theory of Communicative Action. Volume 1: Reason and the Rationalization of Society. Translated by T. McCarthy. Boston: Beacon Press.

Habermas, J. (1987). Theory of Communicative Action. Volume 2: Lifeworld and System: A Critique of Functionalist Reason. Translated by T. McCarthy. Boston: Beacon Press.

Habermas, J. (1998). The Inclusion of the Other. Edited and translated by C. Cronin and P. de Greiff. Boston, MA: MIT Press.

Habermas, J. (1990). Moral Consciousness and Communicative Action. Translated by Ch. Lenhardt. Cambridge: Polity Press.

Habermas, J. (2003). Truth and Justification. Translated by B. Fultner. Cambridge, Mass.: The MIT Press.

Habermas, J. (2009). Between Naturalism and Religion: Philosophical Essays. Translated by C. Cronin. Cambridge: Polity Press.

Hvidt, E A. et al. (2021). A Colonized General Practice? A Critical Habermasian Analysis of How General Practitioners Experience Defensive Medicine in Their Everyday Working. Health, 25 (2), pp. 141-158.

Jones, I. R. (2001). Health Care Decision Making and the Politics of Health. In: Scambler G. (ed.), Habermas, Critical Theory and Health. London: Routledge, pp. 68-85. 
Klieme, E. et al. (2007). Zur Entwicklung nationaler Bildungsstandards. Eine Expertise. Available at: http://edudoc.ch/record/33468/files/develop_standards_nat_form_d.pdf [Accessed: 29 July 2021].

Kodeks Etyki Lekarskiej (2003). Available at: https://nil.org.pl/dokumenty/kodeks-etyki-lekarskiej [Accessed: 29 July 2021].

Langford, A. T., et al. (2019). Partnerships to Improve Shared Decision Making for Patients with Hypertension - Health Equity Implications. Ethnicity \& Disease, 29 (Suppl 1), pp. 97-102.

Leanza, Y., Boive, I., and Rosenberg, E. (2013). The Patient's Lifeworld: Building Meaningful Clinical Encounters between Patients, Physicians and Interpreters. Communication Meicine, 10 (1), pp. 13-25.

Lee, P. R. and Emmott C. (1978). Health-care System. In: Reich W. T. (ed.), Encyclopedia of Bioethics. Vol. 2. London: Collier Macmillan Publishers, pp. 610-619.

Napiwodzka, K. (2021). The Shared Decision-Making Model and Practical Discourse to Foster the Appreciation of Patients' Value Preferences in Polish Healthcare. In: Schildmann, J., Buch, Ch., and Zerth, J. (eds.), Defining the Value of Medical Interventions. Normative and Empirical Challenges. Stuttgart: Verlag W. Kohlhammer, pp. 135-157.

Newton-Howes, G., Pickering N., and Young G. (2019). Authentic Decision-making Capacity in Hard Medical Cases. Clinical Ethics, 14 (4), pp. 173-177.

Program akredytacji podstawowej opieki zdrowotnej. Zestaw standardów akredytacyjnych (2011). Available at: https://www.cmj.org.pl/dodatki.php?plik=5601b8718fcf959dd96d9e22921c809b [Accessed: 29 July 2021].

Rodrian-Pfennig, M. (2014). Karriere und Kontext des Kompetenzbegriffs. Ein skeptischer Rekurs aus der Sicht der Hochschullehre. In: Rodrian-Pfennig, M. et al. (eds.), Reflexive Lehrforschung an der Hochschule. Opladen, Berlin, Toronto: Budrich UniPress.

Rothman, D. J. (1991). Strangers at the Bedside: History of How Law and Bioethics Transformed Medical Decision Making. New York: Basic Books.

Scambler, G. (ed.) (2001). Habermas, Critical Theory and Health. London: Routledge.

Stefaniak, K. (2011). Władza i tożsamość w komunikacji lekarz-pacjent. Wrocław: ATUT.

Svenaeus, F. (2003). Hermeneutics of Medicine in the Wake of Gadamer: The Issue of Phronesis. Theoretical Medicine and Bioetehics, 24 (5), pp. 407-431.

Swales, J. M. (2016). Reflection on the Concept of Discourse Community. ASp le Revue du GERAS $S^{\wedge}, 69$, pp. 1-12.

Szahaj, A. (ed.) (1990). Krytyka, emancypacja, dialog. Jürgen Habermas w poszukiwaniu nowego paradygmatu teorii krytycznej. Warszawa: Universitas.

Walker, P. and Lovat T. (2016). Dialogic Consensus in Clinical Decision Making. Journal of Bioethical Inquiry, 13 (40), pp. 571-580.

Walseth, L. T., Abildsnes, E., and Schei, E. (2011). Lifestyle, Health and the Ethics of Good Living. Health Behaviour Counselling in General Practice. Patient Education and Counseling 83 , pp. $180-184$. 